\title{
Molecular differentiation of the Murraya paniculata Complex (Rutaceae: Aurantioideae: Aurantieae)
}

\author{
Chung Huy Nguyen ${ }^{1,2}$, G. Andrew C. Beattie ${ }^{2}$, Anthony M. Haigh ${ }^{2 *}$ D, Inggit Puji Astuti ${ }^{3}$, David J. Mabberley ${ }^{4,5,6}$,
} Peter $\mathrm{H}$. Weston ${ }^{4}$ and Paul Holford ${ }^{2}$

\begin{abstract}
Background: Orange jasmine has a complex nomenclatural history and is now known as Murraya paniculata (L.) Jack. Our interest in this common ornamental stemmed from the need to resolve its identity and the identities of closely related taxa as hosts of the pathogen 'Candidatus Liberibacter asiaticus' and its vector Diaphorina citri. Understanding these microbe-vector-plant relationships has been hampered by taxonomic confusion surrounding Murraya at both the generic and specific levels.

Results: To resolve the taxonomic uncertainty, six regions of the maternally-inherited chloroplastal genome and part of the nuclear-encoded ITS region were amplified from 85 accessions of Murraya and Merrillia using the polymerase chain reaction (PCR). Clustering used maximum parsimony (MP), maximum likelihood (ML) and Bayesian inference (BI). Chronograms were produced for molecular dating, and to test the monophyly of Murraya rigorously, using selected accessions of Murraya and 26 accessions of the Rutaceae and Simarubaceae. Sequence data from the ITS and chloroplastal regions suggest that Murraya paniculata (sensu (Swingle WT and Reece CR, The Citrus Industry, p. 190-430, 1967)) can be separated into four distinct but morphologically somewhat cryptic taxa: Murraya paniculata (sensu (Mabberley DJ, Taxon 65:366-371, 2016)), M. elongata, M. sumatrana and M. lucida. In addition, Murraya omphalocarpa was identified as a putative hybrid of M. paniculata and M. lucida with two geographically isolated nothovarieties representing reciprocal crosses. Murraya is monophyletic, and molecular dating suggests that it diverged from Merrillia during the Miocene (23-5 Ma) with this Murraya group speciating and dispersing during the Middle Miocene onwards.
\end{abstract}

Conclusions: The accessions from Asia and Australasia used in this study grouped into biogeographical regions that match herbarium specimen records for the taxa that suggest natural allopatric distributions with limited overlap and hybridity. Murraya paniculata has been distributed around the world as an ornamental plant. The division of the Murraya paniculata complex into four species with a rare hybrid also confirms morphological studies.

Keywords: Murraya, Rutaceae, Phylogeny, Molecular dating, Monophyly

\section{Background}

Orange jasmine, also known as orange jessamine, Chinese box and mock orange, has had a complex nomenclatural history [1]. Its name is now confirmed as Murraya paniculata (L.) Jack, the name most widely used in commerce, as a result of Mabberley's [2] successful proposal to

\footnotetext{
* Correspondence: a.haigh@westernsydney.edu.au

${ }^{2}$ School of Science, Western Sydney University, Locked Bag 1797, Penrith, NSW 2751, Australia

Full list of author information is available at the end of the article
}

conserve a specimen of orange jasmine as the type of this name. It is best known as a common ornamental plant in tropical, subtropical and warm-temperate regions of the world and has diverse uses. In Indonesia and Malaysia, wood ascribed to orange jasmine is used for the hilts of daggers (kris or kreeses) [3-6], bark or leaf extracts are used in folk medicine for a wide range of purposes [7], and roots are a source of the anti-implantation indol alkaloid yuehchukene [8]. It has been used in the breeding of

(c) The Author(s). 2019 Open Access This article is distributed under the terms of the Creative Commons Attribution 4.0 International License (http://creativecommons.org/licenses/by/4.0/), which permits unrestricted use, distribution, and reproduction in any medium, provided you give appropriate credit to the original author(s) and the source, provide a link to the Creative Commons license, and indicate if changes were made. The Creative Commons Public Domain Dedication waiver (http://creativecommons.org/publicdomain/zero/1.0/) applies to the data made available in this article, unless otherwise stated. 
rootstocks for citrus, as it may be a source of tolerance to lime and nematodes $[3,9]$.

Our interest in orange jasmine stemmed from the need to resolve its identity and its status as a host of 'Candidatus Liberibacter asiaticus' ( $\alpha$-Proteobacteria), the pathogen that causes the most severe form of huanglongbing (HLB or 'yellow shoot disease' or citrus greening), a devastating, incurable disease of citrus [10], and Diaphorina citri Kuwayama (Hemiptera: Sternorrhyncha: Psylloidea), the primary and most widespread vector of the pathogen [11]. Various authors have suggested that orange jasmine can be a host of 'Candidatus Liberibacter asiaticus' [12-15] whilst others [16-18]) concluded that it is not [19]. Understanding this microbe-plant relationship has been hampered by taxonomic confusion surrounding Murraya at both generic and specific levels.

At the generic level, the question of whether Murraya should be circumscribed broadly to include the curry leaf 'Murraya koenigii (L.) Spreng.' and its close relatives, or more narrowly to exclude them has recently been resolved decisively by molecular systematic research [20-25] which has shown that curry leaf is Bergera koenigii L., as originally described. Murraya sensu lato is polyphyletic and the type of the genus; $M$. paniculata, is more closely related to Merrillia than to Bergera. Swingle and Reece [3] considered Merrillia to be related to an ancestor of Murraya; however, they placed Murraya and Merrillia in separate subtribes in the tribe Clauseneae. Recent molecular studies have placed Merrillia and Murraya (sect. Murraya) in the tribe Aurantieae [26], as confirmed by others [20-25].

At the species level, as discussed in detail by Mabberley $[1,2]$, taxonomic confusion of orange jasmine has existed from the mid-eighteenth century with its first description as Camunium vulgare by Rumphius [4] who ascribed a plate of an unrelated species to the description [2]. Additional confusion was introduced by Linneaus $[27,28]$ with his descriptions of Murraya exotica and Chalcas paniculata (M. paniculata). Because the Latin polynomials used to describe species in the eighteenth Century were necessarily short and published descriptions were not linked to type specimens, species concepts were rather broad [29] with, for example, one name being applied to what is now recognised as several different species in different genera or conversely, multiple names being applied to what is now recognised as one species. Moreover, interpretation of species was commonly based on brief descriptions [30] and illustrations, rather than examination of specimens and continued in this manner until some years after the introduction of the first International Rules of Botanical Nomenclature $[29,31]$. Consequently, the lack of detailed distinguishing characters and type specimens may have persuaded subsequent authors to synonymise or subsume M. exotica with (in) M. paniculata or the reverse $[3,6]$. Others have described them morphologically as two species [32], and some have used chemotaxonomic methods to distinguish these two species $[8,33]$. Despite the 20 years of effort spent typifying Linnaean plant names [29], taxonomic confusion remains for the Murraya paniculata Complex. Resolution of this confusion is possible using molecular techniques both at the generic [24, 25] and at the species level [34].

From the beginning of research on HLB in Indonesia from 2003 to 2009, funded by the Australian Centre for International Agricultural Research, we observed differences among plants that suggested the presence of two morphologically distinct species of Murraya in Java. Here we report molecular differentiation of 82 accessions of plants of the genus Murraya, including plants that have been identified as M. elongata A.DC. ex Hook.f., M. lucida (G. Forst.) Mabb., M. omphalocarpa Hayata, M. paniculata (L.) Jack, M. cyclopensis Astuti \& Rugayah and M. sumatrana Roxb. Our work is based on six regions of the maternally-inherited chloroplastal genome and the internal transcribed spacers (ITS) of nuclear ribosomal DNA region. We used Merrillia caloxylon (Ridl.) Swingle (Aurantieae) and two accessions from Murraya sect. Bergera (sensu [35, 36]), from the tribe Clauseneae, as outgroups. We used this data to address the question of whether the $M$. paniculata Complex consists of a single species, two species or may include additional cryptic species, as well as to determine the phylogeny of Murraya.

\section{Results}

Phylogeny derived from the six chloroplastal regions

The phylogenetic analysis of the individual chloroplastal regions did not show any topological incongruence between significantly supported components among the individual analyses (data not shown). However, before combining the chloroplastal data sets for further analysis, ILD tests were performed among all pairwise combinations of the following regions: trnL-F, psbM$\operatorname{trn} D^{\mathrm{GUC}}$ and $\operatorname{trn} C^{\mathrm{GCA}}-y c f 6$. These regions are representative of those with different nucleotide substitution models $(\mathrm{F} 81+\mathrm{G}, \mathrm{F} 81$, GTR, respectively). The tests returned $P$ values of $1.0,0.174$, and 0.506 for $\operatorname{trn} L-F$ and $p s b M-\operatorname{trn} D^{\mathrm{GUC}}$, $\operatorname{trnL}-F$ and $\operatorname{trn} C^{G C A}-y c f 6$ and $p s b M$ $\operatorname{trn} D^{\mathrm{GUC}}$ and $\operatorname{trn} C^{G C A}-y c f 6$, respectively. These results show that the sequences of chloroplastal regions are homogeneous and can legitimately be combined.

The length of the alignment of combined sequence data from the six different regions was $4627 \mathrm{bp}$ of which $114(2.46 \%)$ were phylogenetically informative characters (PICs). The majority rule consensus tree resulting from our Bayesian analysis of the combined plastid data set is shown in Fig. 1. The cladograms produced from 


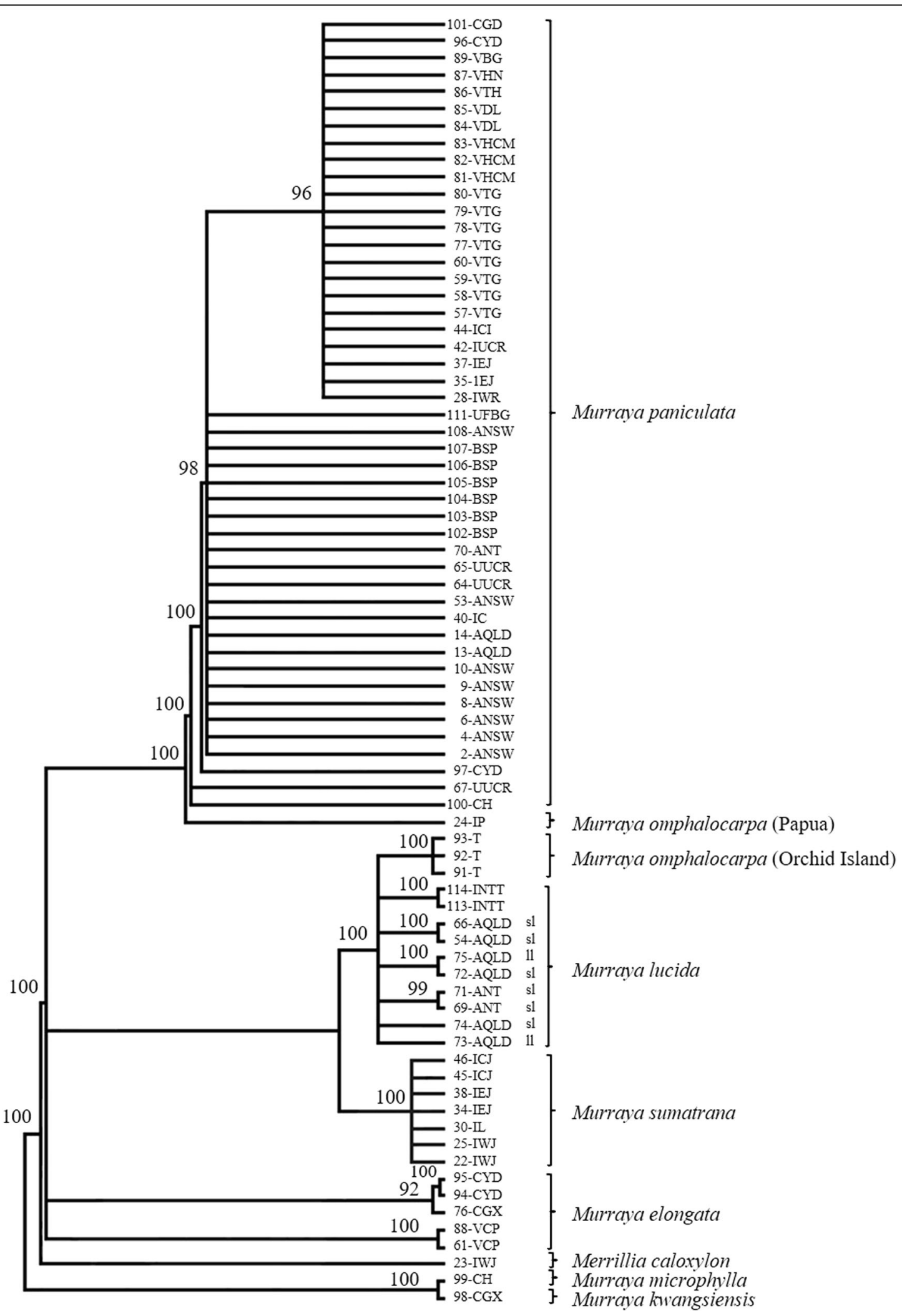

Fig. 1 (See legend on next page.) 
(See figure on previous page.)

Fig. 1 Bayesian inference tree based on the combined sequences of the six chloroplastal regions from accessions of Murraya and Merrillia. Murraya kwangsiensis and M. microphylla were used as the outgroup and posterior probabilities are shown above each branch. The model of nucleotide substitution used was GTR $+\mathrm{G}$ and the Markov chains were run for 5,000,000 generations (burnin = 1,250,000 generations). 'sl' small leaflet and 'Il' large leaflet forms of Murraya lucida from Australia

parsimony and likelihood analyses of the data sets (with and without indels coded as binary characters) were topologically congruent with the Bayesian tree (see Fig. 1, Additional file 1: Figure S1).

In most of our chloroplastal trees, Murraya accessions formed clusters corresponding to the following taxa: $M$. elongata, M. lucida, M. paniculata, and M. sumatrana. In all analyses of the chloroplastal data, Merrillia caloxylon was placed as sister to the Murraya accessions and M. kwangsiensis (Huang) Huang and M. microphylla (Merr. et Chun) Swingle were not placed within the Murraya clusters. In most chloroplastal analyses, $M$. lucida clustered with M. sumatrana. Within this group, accessions of $M$. lucida clustered with accessions of $M$. omphalocarpa from Orchid Island to form a sub-group that was sister to the cluster of $M$. sumatrana accessions. Within the M. omphalocarpa - M. lucida cluster the accessions of $M$. omphalocarpa grouped together as did the accessions of $M$. lucida from Indonesia. However, the accessions of M. lucida from Australia were not resolved as a cluster, with three pairs of accessions and two single accessions forming a 7-way polytomy with $M$. omphalocarpa and M. lucida from Indonesia. In the MP analysis, all the M. elongata accessions grouped together, whereas using ML and BI these accessions separated into two unresolved sub-groups based on geographical origin with three accessions from China in one group and two from Việt Nam in the second.

In the $M$. paniculata group, in the MP, ML and BI analyses, accessions 24-IP from Papua, 67-UUCR from the University of California, Riverside, $100-\mathrm{CH}$ from Hainan, China and 97-CYD from Yingde, China formed a basal paraphyletic grade. The remaining accessions cluster together in a 22-way polytomy within which 23 accessions group together as a sub-cluster. The ungrouped accessions in this polytomy are predominantly from Australia and Brazil, including the dwarf cultivar, 'Min-a-Min' (70-ANT), whereas the sub-cluster predominantly contains accessions from Việt Nam and Indonesia. Other accessions of M. paniculata from China and the USA are distributed between the polytomy and the sub-cluster.

The chloroplastal sequences contain 42 phylogenetically informative indels (psbM-trn $D^{\mathrm{GUC}}: 10$; $\operatorname{trnL}-F$ : 6; $\operatorname{trn} C^{G C A}-y c f 6: 9 ;$ rps16: 7; matK-5'trnK: 6; rps4-trnT: 4) and the cladogram derived from their analysis is shown in Additional file 1: Figure S2. The results show that all Murraya paniculata accessions form a single cluster that separates from all accessions of the other clusters including those of $M$. omphalocarpa. Within the $M$. paniculata cluster, two accessions from China (97-CYD and $100-\mathrm{CH}$ ) weakly group together but not with other accessions from China. Accessions 111-UFBG from Florida and 82-VHCM from Việt Nam also weakly group together but not with other $M$. paniculata accessions from these countries. Accession 24-IP from Papua did not group with the $M$. paniculata accessions. Among the M. elongata, M. lucida, and M. sumatrana accessions, there is little resolution, with any resolution occurring being based on their geographical origin. For example, the $M$. sumatrana accessions from Indonesia form a cluster, as do the $M$. omphalocarpa accessions from Taiwan and the M. lucida accessions from the Northern Territory. However, many accessions formed a large polytomy.

\section{Phylogeny derived from the ITS region}

The phylogenetic relationships among accessions of Murraya and Merrillia were also examined using part of the nuclear rDNA ITS region. This analysis used 53 accessions of species of Murraya and Merrillia, which represent every clade and sub-clade found in the chloroplastal analyses. The sequence matrix consists of $625 \mathrm{nu}-$ cleotides of which 51 sites (8.6\%) were PICs. The trees produced by MP, ML and BI are identical; the tree produced by BI is shown in Fig. 2 (see Additional file 1: Figure S3) and consists of four main clusters containing: (1) accessions of $M$. omphalocarpa from Orchid Island plus all M. paniculata accessions including 'Min-a-Min' but not 24-IP from Papua; (2) M. elongata accessions from China and Việt Nam; (3) M. sumatrana accessions from Java; (4) M. lucida from Indonesia, M. lucida from Australia, and 24-IP, with the accessions of M. lucida from the Northern Territory of Australia separating from those from Queensland. Merrillia caloxylon was resolved as the sister group of Murraya and M. microphylla was not placed among the Murraya clusters. The placement of 24-IP with M. lucida accessions and the placement of the accessions of $M$. omphalocarpa from Orchid Island with M. paniculata accessions are both strongly incongruent with their positions in the cpDNA trees.

\section{Phylogeny derived from combination of sequences of 6 chloroplastal genes and the ITS region}

Before combining the sequences of chloroplastal and ITS regions for phylogenetic analysis, an incongruence 


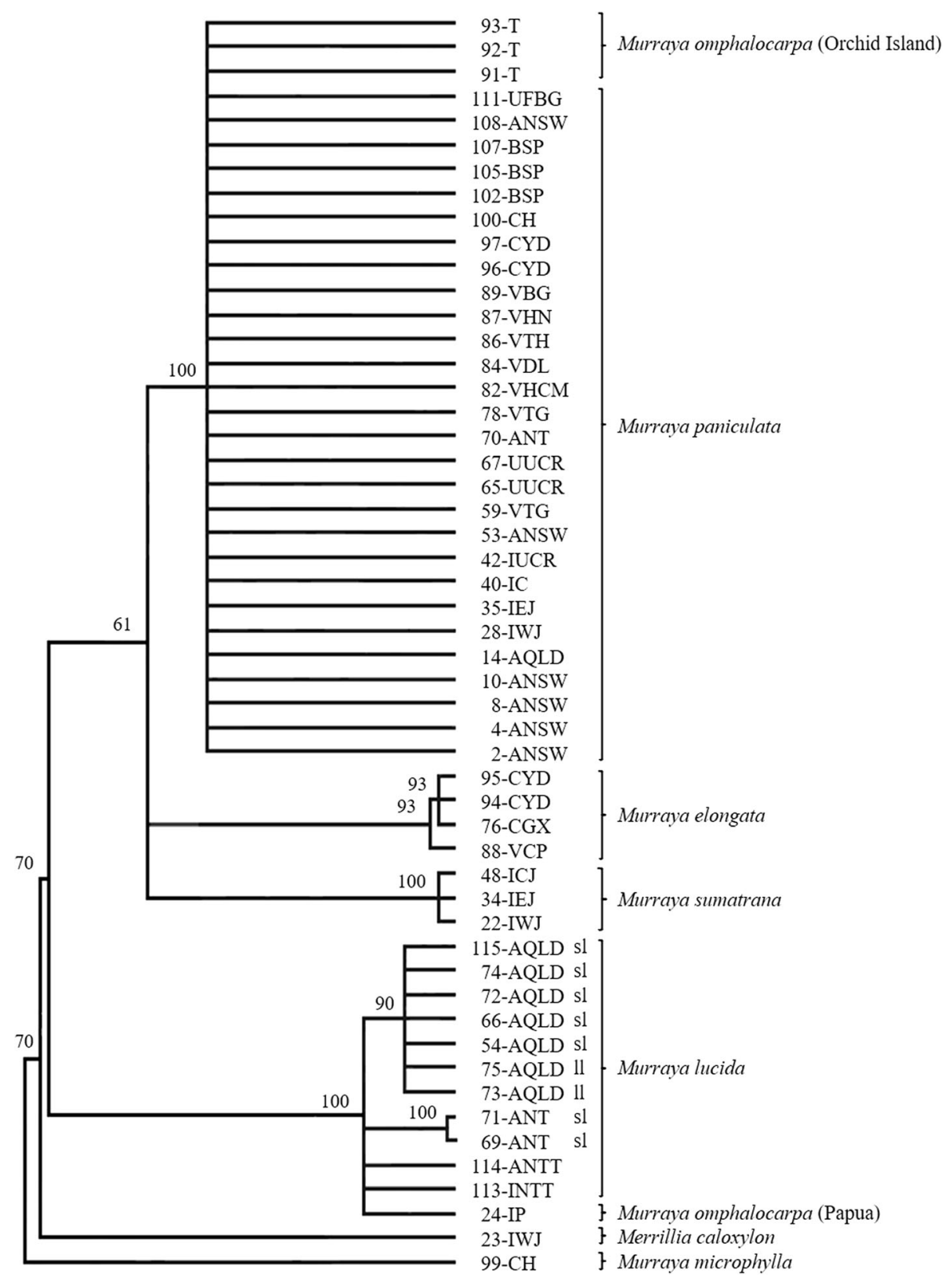

Fig. 2 Bayesian inference tree based on the ITS sequences of accessions of Murraya and Merrillia. Murraya microphylla was used as the outgroup and posterior probabilities are shown above each branch. The model of nucleotide substitution used was GTR $+\mathrm{G}$ and the Markov chains were run for 5,000,000 generations with a sample frequency of 10 and a burnin of 1,250,000 generations. 'sl' small leaflet and 'Il' large leaflet forms of Murraya lucida from Australia

length difference (ILD) test was performed between the data from these two regions from 51 accessions of Murraya and Merrillia caloxylon: this test returned a $P$ value of 0.001 , indicating that the data sets were heterogenous and should not be combined. When the ILD test was repeated with data from 24-IP and the $M$. omphalocarpa accessions from Orchid Island removed, it returned a $\mathrm{P}$ value of 0.03 . Therefore, following this test, MP and BI analyses were performed on the combined chloroplastal and ITS data from 47 accessions of Murraya and Merrillia, but without the data from 24-IP and Murraya omphalocarpa from Orchid Island. This resulted in a sequence matrix consisting of 5218 nucleotides of which, 123 sites (2.35\%) were PICs. The two trees resulting from these analyses are congruent and similar, and the tree resulting from Bayesian inference is presented in Fig. 3 (see Additional file 1: Figure S4). 


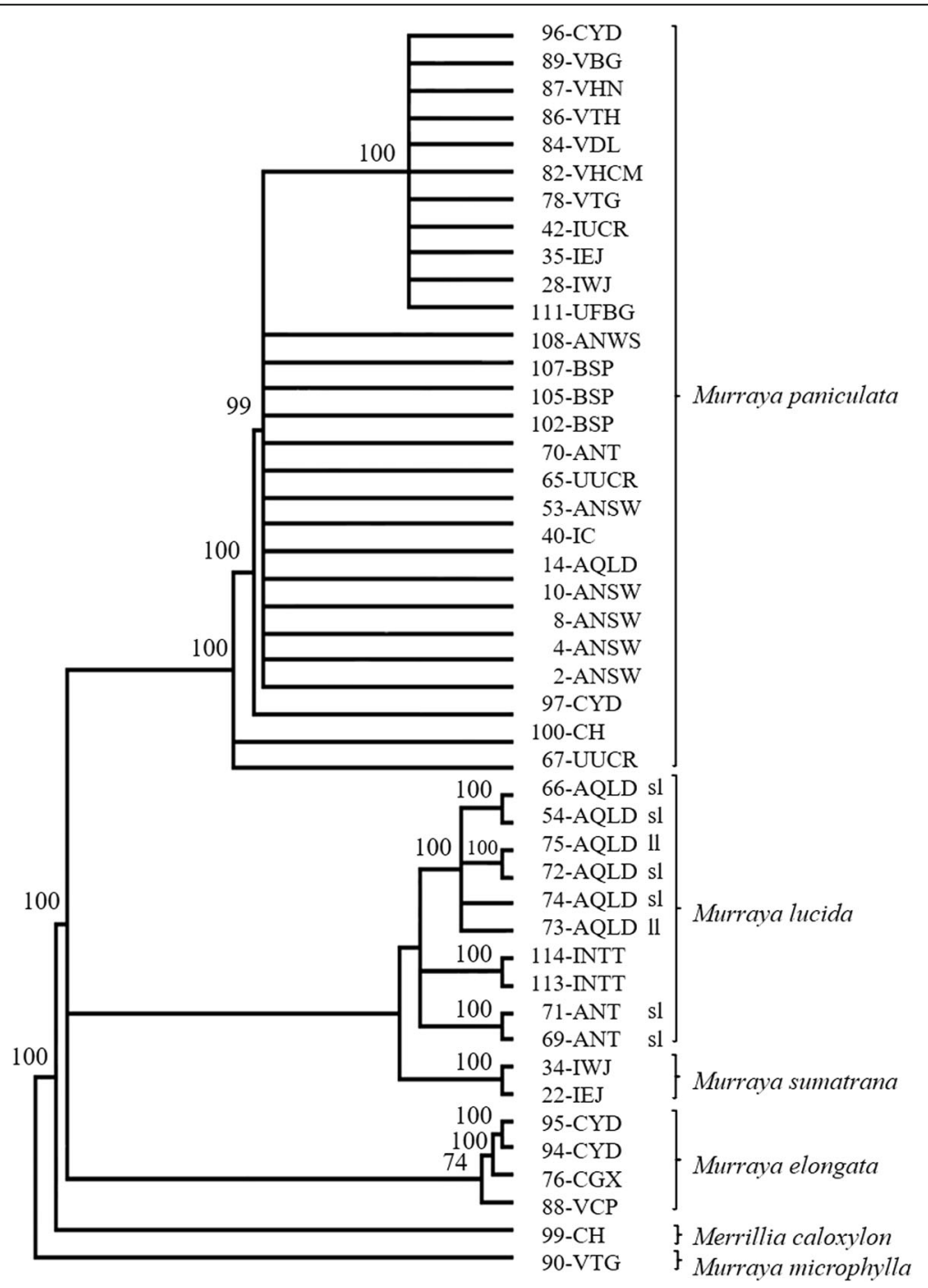

Fig. 3 Bayesian inference tree based on the ITS region combined with 6 chloroplastal regions of accessions of Murraya and Merrillia. Murraya microphylla was used as the outgroup and posterior probabilities are shown above each branch. The model of nucleotide substitution used was GTR $+\mathrm{G}$ and the Markov chains were run for 600,000 generations with a sample frequency of 10 and a burnin of 150,000 generations. 'sl' small leaflet and 'Il' large leaflet forms of Murraya lucida from Australia

In the cladograms produced by MP, ML and BI, $M$. paniculata accessions form a cluster that is clearly separated from the M. elongata, M. lucida and M. sumatrana accessions; the internal topology of the $M$. paniculata cluster is identical between these analyses. Using BI, all accessions of $M$. elongata form a single cluster separate from the other accessions, whereas using MP these accessions form two clusters based on geographic origin. With regards to the M. lucida and $M$. sumatrana accessions, a cluster is formed with the $M$. sumatrana accessions being sister to those of M. lucida. Using BI, the M. lucida accessions form a three-way polytomy consisting of two groups of $M$. lucida accessions from Australia, one from Queensland and the other from the Northern Territory, the third being those of M. lucida from Indonesia. However, using MP, the accessions of M. lucida from Indonesia are sister to the two Australian groups of M. lucida.

\section{Monophyly of Murraya and dating of divergence}

The ages of divergence and phylogenetic placement of accessions of Murraya and Merrillia was assessed against other species from the Rutaceae using chloroplastal (Fig. 4) or ITS sequences (Fig. 5). Both chronograms clearly show that the Merrillia and the four groups of Murraya accessions formed a single, distinct cluster that was separate from rutaceous accessions that have been placed within the subfamilies Toddalioideae and Aurantioideae (sensu [3]), in particular the accessions of Murraya were separate from those of $B$. 


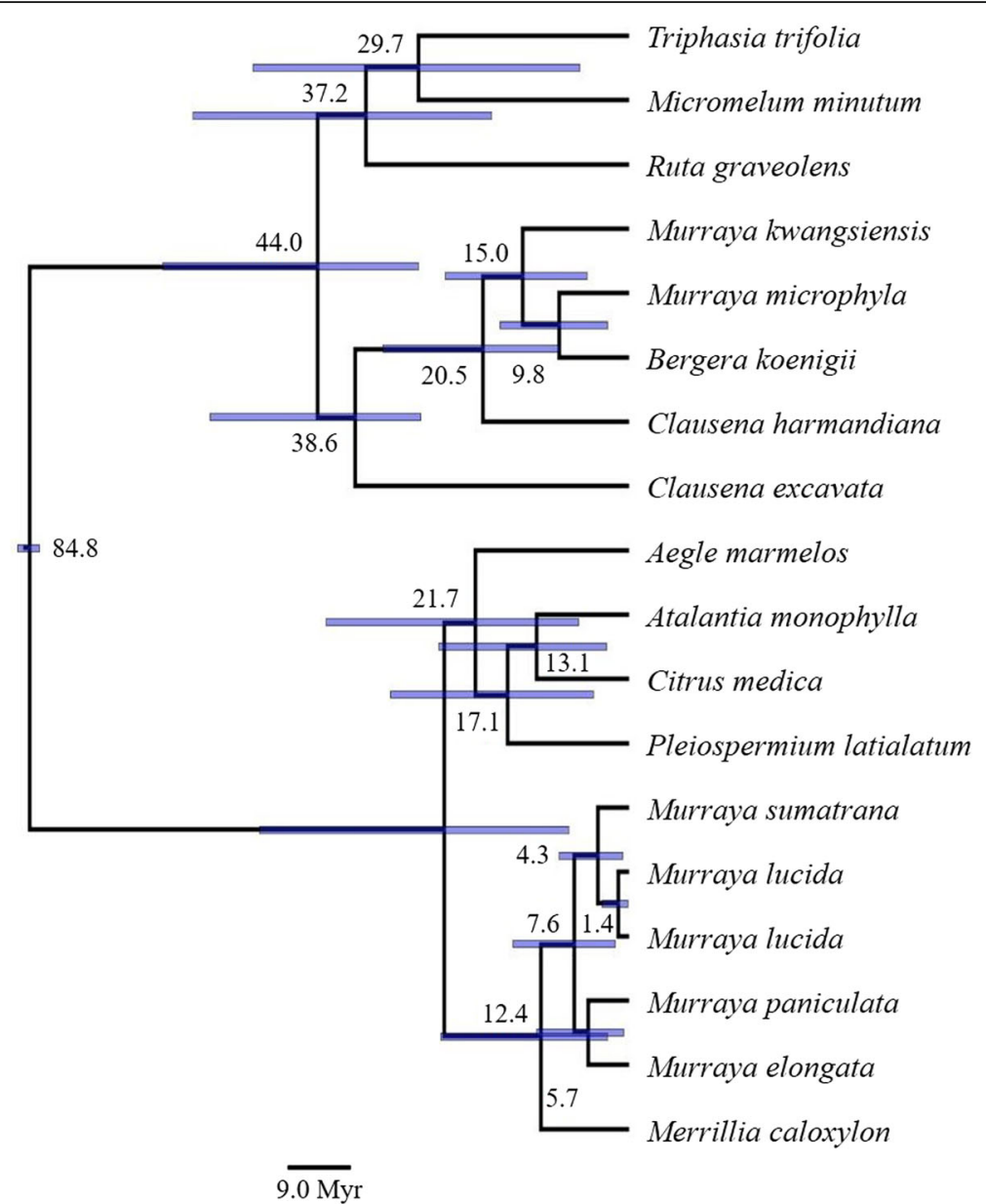

Fig. 4 Maximum clade credibility tree produced using the BEAST suite of programs based on the combined sequences of five chloroplastal regions. The values next to the nodes are the ages (Ma). The bars represent the $95 \%$ highest posterior density

koenigii, M. kwangsiensis and M. microphylla which clustered together. The analysis of the ITS data also shows that Murraya alata Drake (a southern Chinese and Indochinese species cultivated in the South China Botanical Gardens) grouped with the other Murraya accessions.

Dating of the divergence of these accessions differed between the analyses of the two data sets, with the ITS data giving older times for divergence than the chloroplastal data. The divergence between Murraya and Merrillia was estimated to have occurred 12.4 (95\% HPD: 3.0-26.6) $\mathrm{Ma}$ from the chloroplastal data and 31.4 (14.3-50.7) Ma from the ITS data. The mean ages for divergence among the Murraya accessions was from 1.47.6 $\mathrm{Ma}$ according to the chloroplastal data and from 4.1-16.7 Ma from the ITS data; within each of these analyses, there is substantial overlap in the HPD intervals. Additionally, the dating of the divergence between the $M$. paniculata and $M$. elongata accessions in the analysis of the chloroplastal data of $5.7(0.6-13.0) \mathrm{Ma}$ was similar to that between the M. paniculata and $M$. elongata and $M$. sumatrana accessions in the ITS analysis of $7.1(1.7-13.8)$ Ma.

\section{Murraya omphalocarpa putative hybrids}

In the analysis of the six chloroplastal regions, the $M$. omphalocarpa accession, 24-IP, from Papua forms a clade sister to all M. paniculata accessions; whereas the M. omphalocarpa accessions from Orchid Island Taiwan form a clade that is sister to accessions of M. lucida (Fig. 1). In contrast, in the analysis of the ITS sequences, the M. omphalocarpa accessions from Orchid Island are part of the polytomy of $M$. paniculata accessions, but the $M$. omphalocarpa accession from Papua lies within the $M$, lucida accessions (Fig. 2). These results suggest that $M$. omphalocarpa is a putative natural hybrid between M. paniculata and M. lucida that has evolved by different crosses in each location. In Papua, the female parent was M. paniculata; whereas on Orchid Island the female parent was M. lucida. 


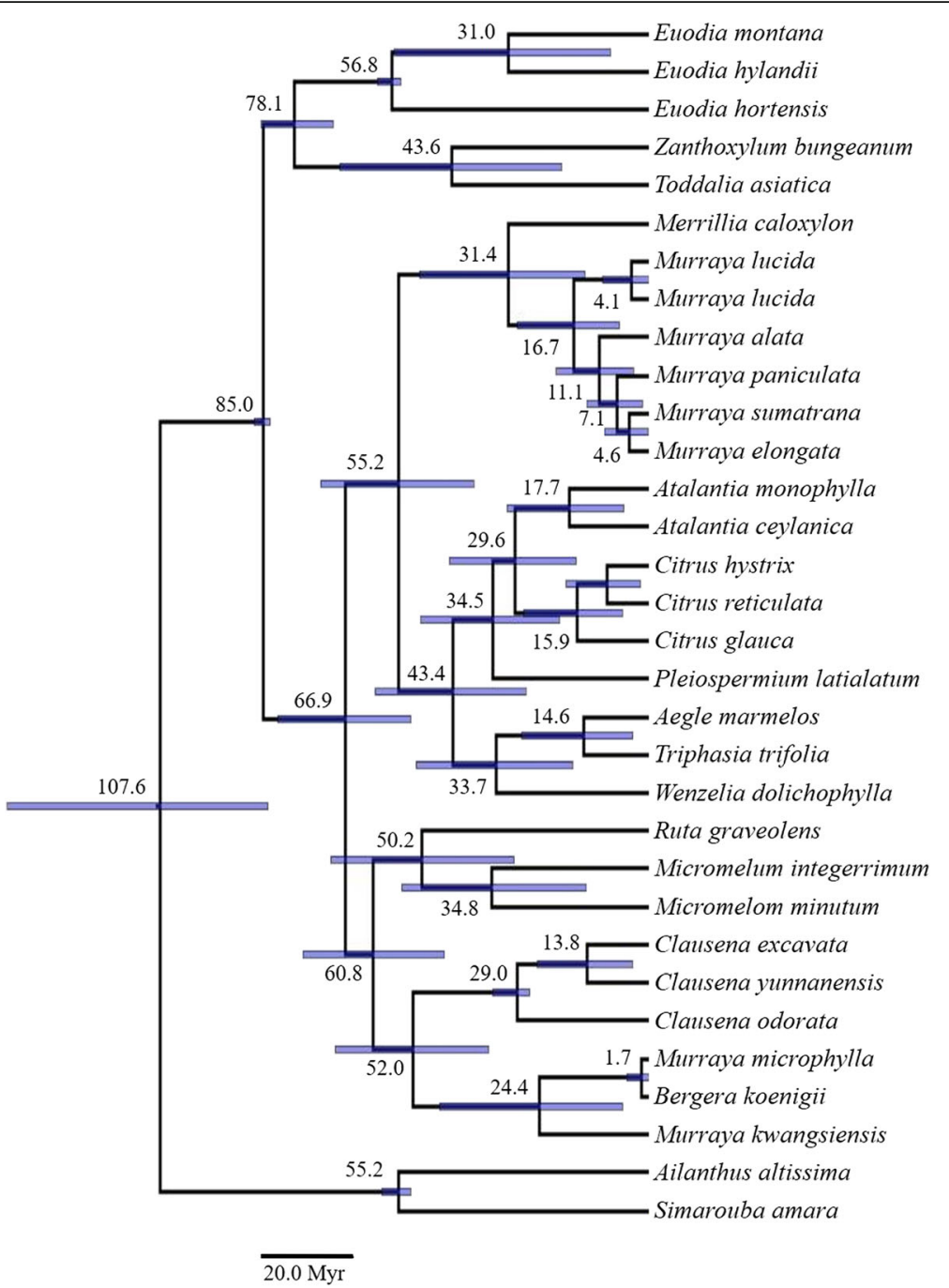

Fig. 5 Maximum clade credibility tree produced using the BEAST suite of programs based on ITS regions. The values next to the nodes are the ages (Ma). The bars are the $95 \%$ highest posterior density

\section{Discussion}

This study has examined the phylogenetic relationships among wild and cultivated accessions of the Murraya paniculata Complex from mainland Asia, the Malay Archipelago, Australasia, and California, Florida and Brazil in the Americas. In all analyses, $M$. paniculata sensu stricto accessions formed a cluster separate from the other accessions and the taxonomic implication of this is discussed below. Also, in all analyses, accessions of the mainland M. elongata (M. 'asiatica' in Nguyen [37]) also formed a distinct cluster or clusters separate from all other accessions.

In the analysis of the chloroplastal regions, accessions of the M. lucida (M. ovatifoliolata in Nguyen [37]) and M. sumatrana ('M. paniculata' in Nguyen [37]) groups formed a third cluster with the two groups forming sister sub-clusters. However, with the ITS data, accessions of $M$. lucida formed a cluster that was weakly supported as the sister group of the rest of the complex. Taken together, the sequence data from the ITS and chloroplastal regions suggest that, based on the sampling to date, $M$. paniculata (sensu [3]) can be separated into four distinct but morphologically somewhat cryptic taxa: M. paniculata (sensu [1]), M. elongata, M. sumatrana and $M$. lucida (syn. M. heptaphylla Span., M. paniculata var. zollingeri Tan. and $M$. paniculata var. ovatifoliolata Engl.). The recognition of four taxa is in concordance with a study of their morphology [37].

Swingle and Reece [3] placed Murraya and Merrillia in separate subtribes in tribe Clauseneae: Clauseninae and Merrilliinae. They considered Merrillia to be an abnormal member of Clauseneae and possibly related to ancestral forms of Murraya. Tanaka [38] and But et al. [35] proposed the division of Murraya (sensu lato) into 
sect. Murraya and sect. Bergera. More recent studies have moved Merrillia and Murraya (sect. Murraya) to tribe Aurantieae [26], and further studies [20-25] have confirmed this. Analysis of both the chloroplastal and ITS regions from accessions of the four groups of the Murraya paniculata Complex and Merrillia used in this study clearly show that Murraya is monophyletic and sister to Merrillia caloxylon. The accessions of $M$. kwangsiensis, M. microphylla and B. koenigii are more closely related to one other and to accessions of Clausena than to the accessions of the Murraya paniculata Complex. Our results support the disintegration of Murraya (sensu lato) as Murraya (sensu stricto) and Bergera with Merrillia and Murraya constituting subtribe Merrilliinae sensu [3], of tribe Aurantieae [26]. Further, $M$. microphyla and M. kwangsiensis do not belong within Murraya and should be transferred to Bergera.

Although the trees derived from chloroplastal data and those from the nuclear ITS region were largely in agreement, some incongruence was found. Incongruence between gene trees for comparable samples of taxa are not uncommon [39]. For example, Seelanan et al. [40] found such differences among members of the Gossypieae [Malvales: Malvaceae] as well as within the genus Gossypium L., and Barber et al. [41] showed incongruence between gene trees among 23 species of Sideritis Tourn. ex L. [Lamiales: Labiatae/Lamiaceae]. In rare, extreme cases (e.g. [42]) the majority of clusters in one gene tree are incongruent with those in another. In this study, with respect to the chloroplastal data, the accession 24-IP from Papua was always placed in the M. paniculata cluster, whilst using the ITS region, it grouped with M. lucida accessions. A second anomaly was the placement of the three accessions of $M$. omphalocarpa from Orchid Island. Using the chloroplastal data, this taxon grouped with M. sumatrana and M. lucida accessions, whilst in the analyses using the ITS region, it grouped within the M. paniculata cluster. These anomalies are the result of well supported phylogenies from the chloroplastal and ITS analyses and, as such, fit into the "hard incongruence' category proposed by Seelanan et al. [40].

Wendel and Doyle [39] suggested that phylogenetic incongruence may occur due to technical issues such as insufficient data or taxon sampling. However, they also suggested that incongruence may reflect something interesting about the biology of the taxa under study and may be due to processes at various organisational levels, from the gene to organism to taxon levels. Two reasons often thought to cause incongruence are incomplete lineage sorting and introgressive hybridisation. With incomplete lineage sorting, an ancestral polymorphism in a gene or haplotype that was present before a speciation event is inherited by one or both resulting lineages when speciation occurs [43]. The allele/haplotype causing the anomaly may have evolved independently for some time before speciation has occurred. Introgressive hybridization occurs when genetically differentiated taxa interbreed, after which extensive backcrossing occurs. The time of divergence between an incongruent allele/ haplotype resulting from hybridization and its most closely related allele/haplotype can be younger than the speciation event at which the parents of the hybrid diverged [44]. Hybridization is an important evolutionary mechanism in plants [45-47]. It has been estimated that $25 \%$ of plant species hybridize [48] and Rieseberg et al. [49] provide a list of $\sim 90$ species where incongruence between molecular markers is thought to be due to hybridization and introgression. Hybridization provides a simple explanation for the anomalous data found in this study, with accession 24-IP from Cycloop in Papua being formed from a hybridization event between $M$. paniculata as the female parent and M. lucida as the male parent. In contrast, M. omphalocarpa from Orchid Island, Taiwan, appears to result from hybridization occurring between M. lucida as the female parent and $M$. paniculata as the male parent. Tippery and Les [50] recently identified a natural hybrid of Nymphoides based on a similar hard incongruence between chloroplastal and ITS data.

Although differences occurred between the placement of taxa and the dates of divergence between the ITS and chloroplastal data, the molecular dating suggests that Murraya diverged from Merrillia during the Miocene (23-5 Ma) with the Murraya paniculata Complex speciating and dispersing during the Middle Miocene onwards. Pfeil and Crisp [22] give a more recent date for the divergence between Merrillia and Murraya namely 9.2 Ma. However, they used dates for the age of the Rutaceae of around 54-59 Ma-we used 80 Ma for the age of the Rutaceae [51]. During the Early Miocene, the Australasian plate came into contact with the Sundaland margin of the Asian plate. The northward movement of the Australasian plate caused episodes of uplift and the accretion of various terranes, and the subduction beneath Indonesia would have caused widespread volcanism resulting in a chain of island arcs [52-56]). About $10 \mathrm{Ma}$, the gap between the Australian and Asian plates was at its narrowest and the areas of possible land were relatively extensive facilitating the movement of plants and animals [53].

Today, species of Murraya occur naturally in south and eastern mainland Asia, the Indonesian Archipelago, the Philippines and Australasia while Merrillia caloxylon is native to Thailand, Malaysia (Peninsular and Sabah) and Sumatra [57, 58]. The timing of speciation divergence and the current natural distribution of Merrillia caloxylon, M. elongata, M. lucida and M. sumatrana in Malesia, between mainland Asia and Australia, suggests 
that Merrillia and Murraya originated in Sundaland. The fruits of Merrillia caloxylon have a thick, leathery exocarp and are large (approximately $100 \mathrm{~mm}$ long $\times 80$ $\mathrm{mm}$ in diameter [3]); that may have limited their dispersal. Murraya species on the other hand, have small fruits with seeds that can easily be dispersed by birds; seeddispersal by birds has been proposed to account for $40 \%$ of colonization events in various island groups [59].

The distribution of Murraya species parallels that found by Muellner et al. [60] for members of tribe Aglaieae (Sapindales: Meliaceae). These authors suggest that the ancestral area of this tribe group is in Sundaland and that dispersal was a major factor driving divergence. The biogeographic patterns found by Muellner et al. [60] suggest dispersal routes to Wallacea, to the Philippines and to India and Indochina during the Miocene and Pliocene (5-1.6 Ma). Other dispersals of plant species have been suggested during these periods. The meta-analysis of Crayn et al. [61] found similar patterns in 49 clusters that are distributed across Wallace's line from SE Asia to Australia, with mean inferred ages of dispersal ranging from 33.2 to $1.0 \mathrm{Ma}$. They found that of the 44 clusters for which direction of dispersal could reasonably be inferred, 63\%, involved dispersal from Sundaland to Australia and only $27 \%$ from Australia to Sundaland. Ninety percent of the disjunct clusters were found to have animal-dispersed propagules. Sniderman and Jordan [62] found an even greater disparity than did Crayn et al. [61] in the inferred direction of dispersal of disjunct tropical rainforest species, with $89 \%$ of species for which direction could reasonably be inferred dispersing from Sundaland to Australia, the same direction as we have inferred for Murraya.

The results of this study show that M. paniculata, as circumscribed by Swingle and Reece [3], comprises four species, and hybrids:

\section{Murraya lucida}

This species is distributed in eastern and central islands of the Malay Archipelago and Australasia. It is most probably the plant illustrated, albeit inaccurately, as t. 17 of Rumphius's [1, 4]. Herbarium amboinense and poorly described by him as Camunium vulgare, based on material from southern Sulawesi and the central and northern Maluku Islands. It is also most probably the plant on which Burman [63] based his Chalcas camuneng, and consequently Linnaeus $[27,28]$ his Chalcas paniculata. It resembles the annotated specimen (Burman Herbarium G00404451) Kleynhoff sent to Burman from the Botanical Garden in Batavia, Java, in which plants cultivated from the Indonesian archipelago were grown [64, 65]. Following Mabberley's [1] recent retypification of the genus Murraya and synonymy of $M$. heptaphylla with M. lucida [66], M. lucida incorporates $M$. paniculata var. zollingeri in Nusa Tenggara, Sulawesi and Maluku regions of Indonesia, and islands of the Philippines. It also includes the small- and largeleafleted forms sensu Swingle and Reece [3] of M. lucida in north and north-eastern Australia, east to Vanuatu where it was recorded by Johann Reinhold Forster and his son Georg [sic] in 1780 during Cook's second voyage and subsequently described as Limonia lucida by G. Forster [67].

\section{Murraya paniculata}

Murraya paniculata was recently confirmed as the specific name for the species that includes cultivars of the tropical to warm temperate ornamental known as orange jasmine [1]. It is molecularly and morphologically distinctly different from accessions of the other taxa in our study. Our dating evidence suggests separation of this taxon from its closest relatives (either $M$. elongata or $M$. elongata $+M$. sumatrana) is older than divergence within M. lucida. Accessions from China were dispersed throughout the M. paniculata sub-clusters derived from the cpDNA and the ITS analyses, whereas those from other countries were restricted to certain nodes within a sub-cluster. The distributions of these accessions, and pre-1941 herbarium specimens from forested localities in China (IBK, IMDY, NAS, PE and SYS, most accessible through $\mathrm{CVH}$ ) are consistent with an origin of the species in a region that now encompasses Guangxi and Guangdong in southern China, neighbouring areas in Fujian, Hainan, Taiwan, Yunnan, and possibly northern Việt Nam. Kong et al. [8] reported that accessions belonging to M. paniculata ('M. exotica') occurred primarily in maritime sites on red, acid soils in southern China (including Hainan) and northern Việt Nam.

According to Hockings [68], 'Min-A-Min', (\#70-ANT), a dwarf variant of Murraya growing to $1 \mathrm{~m}$ in height, was selected from "M. paniculata var. ovatifoliolata" and propagated by cuttings. In this study, 'Min-A-Min' falls in the M. paniculata cluster. This accession has very small leaves, leaflets and flowers and the leaves of the plant examined and the image (Figure 38) of the plant in Hockings [68] from which 'Min-A-Min' was selected resemble those from other $M$. paniculata accessions. Therefore, it appears to be a form of M. paniculata and is not derived from $M$. lucida.

\section{Murraya sumatrana}

Murraya sumatrana was introduced to India from Sumatra [69]. Jack [5] collected it in Sumatra and initially regarded it as Linnaeus's Chalcas paniculata [6, 70], describing it as $M$. paniculata. The natural distribution of $M$. sumatrana appears to include the western (Indonesia, excluding New Guinea) and central (Borneo and the Philippines) islands of the Malay Archipelago. It 
is the plant called $M$. paniculata in studies funded by the Australian Centre for International Agricultural Research on huanglongbing and Diaphorina citri in Indonesia from 2003 to 2009; orange jasmine in those studies was called M. exotica [71]. Merrill [72] noted that Jack's description was apparently based on material from Penang or Singapore, but this is unlikely. Hunter [73] noted that a young plant yet to ripen seeds in a garden in Penang was the only M. paniculata ('M. exotica') on the island, and the granite-maritime soils of Penang and Singapore do not accord with Jones' [74] account of $M$. sumatrana ('M. paniculata') usually growing on rocky soils or limestone in Borneo. Moreover, in correspondence between Jack and Nathaniel Wallich, it is clear that Jack collected $M$. sumatrana, 'a tree' with 'ovate acuminate leaves' and 'wood most highly valued for making handles of kresses' in Sumatra [6, 75].

\section{Murraya elongata}

Murraya elongata A. DC. ex Hook. f. described from Myanmar [30] was not mentioned by Swingle and Reece [3] either as a good species, or as a synonym of M. paniculata. Kurz [75, 76], Gamble [77] and Brandis [78] mention it, the latter noting that it was possibly a variety of $M$. exotica. Its distribution is associated with limestone karst hills and rocky terrains from Pakistan through India (including the Andaman Islands), Myanmar, Thailand, peninsular Malaysia (including the Langkawi islands), Laos, Việt Nam to southern China, with some overlap with what we consider to be the natural distribution of $M$. paniculata in southern China. Accessions of $M$. paniculata and M. elongata closely group with $M$. alata, another Indochinese-southeast China species recorded from Việt Nam, southwest Guangdong, southwest Guangxi, and southern Hainan $[3,32]$. Based on our study, M. paniculata and M. exotica, as referred to by Kong et al. [8], Li et al. [33], and Huang [79], are M. elongata and M. paniculata, respectively.

Om [80] recorded the presence of $M$. elongata and M. paniculata in Bhutan during studies on HLB and psyllid species occurring on citrus. She recorded Diaphorina citri developing on mandarin (Citrus reticulata Blanco), B. koenigii, $M$. paniculata and $M$. elongata, the latter being the first record of the psyllid developing on a species of Murraya native in the Indian subcontinent. Hollis [81] hypothesised that the Diaphorina citri originated on the subcontinent in association with "a native species of Murraya". Om's [80] studies in Bhutan suggest that the original host of D. citri was, most likely, B. koenigii, and found no evidence to suggest that $M$. elongata is host of 'Candidatus Liberibacter asiaticus'.

\section{Murraya omphalocarpa putative hybrids}

Based on the hard incongruence between the chloroplastal and ITS analyses, our study determined that $M$. omphalocarpa (syn. M. paniculata var. omphalocarpa (Hay.) Tan., M. cyclopensis) is a putative hybrid between $M$. paniculata and $M$. lucida with accessions from Orchid Island, Taiwan, representing a cross between $M$. paniculata as the male parent while the accession from Mount Cycloop, in central northern Papua, represents the reciprocal cross. The Cycloop nothovariety may have resulted from a recent introduction of $M$. paniculata to the region. The Orchid Island nothovariety appears to occur naturally in southern Taiwan, Orchid Island, and northern Luzon in the Philippines. According to specimens we have studied, it occurs within the naturally overlapping distributions of M. lucida and M. paniculata. Thus, M. omphalocarpa may be a natural hybrid.

\section{Conclusion}

The accessions from Asia and Australasia used in this study grouped into biogeographical regions that suggest natural allopatric distributions with limited overlap. Murraya paniculata (orange jasmine) has been distributed around the world. The division of the Murraya paniculata Complex into four species and a hybrid with two nothovarieties conforms with the morphological studies reported in Nguyen [37]. Wider collection of material is now required, particularly from the Philippines and the distinctive Murraya gleniei Thwaites ex Oliv. to ascertain distributional boundaries and any further consideration of taxon ranking. In addition, studies with a wider range of accessions and using other nuclear genes are necessary to test the parentage of the putative hybrids. To date, only Murraya paniculata has been shown to be a host of the ' $\mathrm{Ca}$. Liberibacter asiaticus' and ' $C a$. Liberibacter americanus' causing huanglongbing, and it appears to be a transient host of the pathogens $[19,82]$. The host status of the other taxa urgently needs to be determined.

\section{Methods}

\section{Plant materials and DNA extraction}

Mature leaflets from plants were collected from the wild or from gardens, parks, bushland and germplasm collections in Australia, Brazil, China, Indonesia, Pakistan, Taiwan, the United States of America (USA), and Việt Nam (Additional file 1: Table S1). This resulted in a total of 85 accessions of Murraya and Merrillia that were used for molecular phylogenetic analysis. Total DNA from samples from Australia, China (63-CGD and 68-CGD), Indonesia, Việt Nam, and Florida (111-UFBG and 112-UFBG) was extracted from leaf material following the modified methods of Doyle and Doyle [83] and Warude et al. [84]. The DNA of accessions from Brazil 
and Taiwan was extracted using the method of Murray and Thomson [85] by our colleagues in those countries. The DNA of samples collected from the University of California Riverside (UCR), and from China accessions (76-CGX, 94-CYD, 95-CYD, 96-CYD, 97-CYD, 98-CGX, 99- $\mathrm{CH}, 100-\mathrm{CH}, 101-\mathrm{CGD})$ were extracted using the DNeasy Plant Minikit (Qiagen) and the HP Plant DNA Kit (Omega Bio-Tek), respectively, following the manufacturers' instructions.

\section{DNA amplification}

Six different regions and spacers of the maternallyinherited chloroplastal genome and part of the nuclearencoded ITS region (Table 1) were amplified from DNA extracts using the polymerase chain reaction (PCR). PCR was performed in $25 \mu \mathrm{L}$ volumes using: Taq DNA polymerase (0.2 U) (New England Biolabs); $1 \times$ Thermopol buffer or Thermopol II buffer (New England Biolabs); an equimolar mix of $0.2 \mathrm{mM}$ dNTPs (Fisher Biotech);
$0.4 \mu \mathrm{M}$ each primer; and $5 \mu \mathrm{g}$ acetylated bovine serum albumin. The cycling conditions and magnesium concentrations are given in Table 1.

\section{DNA sequencing and sequence assembly}

Successful amplifications were purified using the Wizard ${ }^{\circ}$ SV Gel and PCR Clean-Up System (Promega) following the manufacturer's instructions. The purified PCR products were quantified using a NanoDrop 1000 spectrophotometer (Thermo Fisher Scientific) and diluted to $50 \mathrm{ng} / \mu \mathrm{L}$. Both strands of purified fragments were sequenced using the same primers as were used for amplification (Table 1) by automated sequencing using an Applied Biosystems 3730XL sequencer at Macrogen Inc. (908 World Meridian Venture Center, \#60-24, Gasan-dong, Geumchun-gu, Seoul 153781, Korea). DNA Baser (v. 2.91, Heracle BioSoft) was used to compile contigs. Sequences were placed in GenBank under the following accession numbers-ITS: MK020214-

Table 1 List of primer sequences and references used for molecular phylogenetic analyses and conditions for PCR

\begin{tabular}{|c|c|c|c|c|c|}
\hline $\begin{array}{l}\text { Target } \\
\text { sequence }\end{array}$ & $\begin{array}{l}\text { Forward and } \\
\text { reverse primer } \\
\text { names }\end{array}$ & $\begin{array}{l}5^{\prime}-3^{\prime} \text { primer } \\
\text { sequence }\end{array}$ & Reference & $\begin{array}{l}\text { Temperature }\left({ }^{\circ} \mathrm{C}\right) \text { and durations }(\mathrm{sec}) \text { of } \\
\text { denaturation, annealing and extension } \\
\text { and total number of cycles }\end{array}$ & $\begin{array}{l}\text { Magnesium } \\
\text { concentration } \\
(\mathrm{mM})\end{array}$ \\
\hline \multirow[t]{2}{*}{$\operatorname{trn} L-F$} & c & $\begin{array}{l}\text { CGA AAT CGG TAG } \\
\text { ACG CTA CG }\end{array}$ & Taberlet et al. [86] & 94,$60 ; 55,60 ; 72,120 ; 30$ & 2 \\
\hline & $f$ & $\begin{array}{l}\text { ATT TGA ACT GGT } \\
\text { GAC ACG AG }\end{array}$ & Taberlet et al. [86] & & \\
\hline \multirow[t]{2}{*}{$\begin{array}{l}\text { psbM- } \\
\operatorname{trnD}^{\mathrm{GU}} \mathrm{C}_{\text {spacer }}\end{array}$} & $\operatorname{trn} D^{G \cup C_{R}}$ & $\begin{array}{l}\text { GGG ATT GTA GYT } \\
\text { CAA TTG GT }\end{array}$ & $\begin{array}{l}\text { Shaw et al. [87]: } \\
\text { modified from Demesure et al. [88] }\end{array}$ & 94,$60 ; 55,60 ; 72,210 ; 35$ & 2 \\
\hline & psbMF & $\begin{array}{l}\text { AGC AAT AAA TGC } \\
\text { RAG AAT ATT TAC } \\
\text { TTC CAT }\end{array}$ & Shaw et al. [87] & & \\
\hline \multirow[t]{2}{*}{ rpsi6 } & rpsF & $\begin{array}{l}\text { GTG GTA GAA AGC } \\
\text { AAC GTG CGA CTT }\end{array}$ & Oxelman et al. [89] & 95,$30 ; 60,60 ; 72,120 ; 33$ & 2 \\
\hline & rpsR2 & $\begin{array}{l}\text { TCG GGA TCG AAC } \\
\text { ATC AAT TGC AAC }\end{array}$ & Oxelman et al. [89] & & \\
\hline \multirow[t]{2}{*}{$\begin{array}{l}\text { matK-5'trnK } \\
\text { spacer }\end{array}$} & matK6 & $\begin{array}{l}\text { TGG GTT GCT AAC } \\
\text { TCA ATG G }\end{array}$ & Johnson and Soltis [90] & 94,$60 ; 50,60 ; 72,90 ; 35$ & 2 \\
\hline & matK5'R & $\begin{array}{l}\text { GCA TAA ATA TAY } \\
\text { TCC YGA AAR ATA } \\
\text { AGT GG }\end{array}$ & Shaw et al. [87] & & \\
\hline \multirow[t]{2}{*}{$\begin{array}{l}\operatorname{trn} C^{G C A}-y c f 6 \\
\text { region }\end{array}$} & ycf6R & $\begin{array}{l}\text { GCC CAA GCR AGA } \\
\text { CTT ACT ATA TCC AT }\end{array}$ & Shaw et al. [87] & 94,$60 ; 50,60 ; 72,210 ; 35$ & 2 \\
\hline & $\operatorname{trnC} C^{G C A} F$ & $\begin{array}{l}\text { CCA GTT CRA ATC } \\
\text { YGG GTG }\end{array}$ & Shaw et al. [87] & & \\
\hline \multirow[t]{2}{*}{$\begin{array}{l}\text { rps4-trnT } \\
\text { spacer }\end{array}$} & $\operatorname{trnT}^{U G U_{R}}$ & $\begin{array}{l}\text { AGG TTA GAG CAT } \\
\text { CGC ATT TG }\end{array}$ & Shaw et al. [87] & 92,$60 ; 55,60 ; 72,180 ; 30$ & 2.5 \\
\hline & rps4R2 & $\begin{array}{l}\text { CTG TNA GWC CRT } \\
\text { AAT GAA AAC G }\end{array}$ & Shaw et al. [87] & & \\
\hline \multirow[t]{2}{*}{ ITS } & ITS1 & $\begin{array}{l}\text { TCC GTA GGT GAA } \\
\text { CCT GCG G }\end{array}$ & White et al. [91] & 94,$90 ; 55,70 ; 72,90 ; 30$ & 2 \\
\hline & ITS4 & $\begin{array}{l}\text { TCC TCC GCT TAT } \\
\text { TGA TAT GC }\end{array}$ & White et al. [91] & & \\
\hline
\end{tabular}


266; trnT: MK214118-198; trnC: MK170731-814; rps16: MK170646-730; trnLF: MK214199-281; trnD: MK170517593; matK: MK170487-516 \& MK170594-645.

\section{Phylogenetic analysis}

Multiple sequence alignments were obtained using ClustalW [92] as implemented in BioEdit v. 5.0.6 [93]; each alignment was checked by eye. Aligned datasets were then analysed using PAUP* 4.0b10 [94] using the maximum parsimony (MP) optimality criterion. Parsimony analysis was performed using treebisection-reconnection branch swapping with a heuristic search with 1000 bootstrap replicates, holding one tree at each step during stepwise addition and with the steepest descent option not in effect. The MP analysis was performed for individual cpDNA chloroplastal regions, for the ITS region, for a combination of all chloroplastal regions and finally for the combined chloroplastal and ITS regions. For the analysis of individual sequences, gaps were treated as missing data and branches with a minimum length of zero were collapsed. The analyses of the combined chloroplastal sequences were based on two matrices, one including gaps coded only as missing characters and the other comprising this first data matrix with the addition of data from indels that were scored for presence or absence using the criteria of Simmons and Ochoterena [95]. In addition, a data matrix that consisted of the presence/absence data from the indels was also subjected to phylogenetic analysis.

The chloroplastal and nuclear ITS sequence data were also analysed using maximum likelihood as implemented in MEGA7 [96] and Bayesian inference as implemented in MrBayes v. 3.1 [97]. Appropriate models of evolution were also determined using MEGA7 prior to analysis. Before BI analysis, an appropriate nucleotide substitution model was identified using hierarchical likelihood ratio tests (hLRTs) implemented in MrModeltest v. 2 [98] for selection of the best-fit model. The Markov chain Monte Carlo simulations (MCMC) were started with 100,000 generations and were run until the standard deviation of split frequencies was below 0.01 . At this stage, the number of generations (ngen) to reach this level was recorded and posterior probability values calculated using a sample frequency of 100. Additionally, analyses were rerun for the combined cpDNA and ITS data following partitioning and evolutionary model identification using PartitionFinder2 [99] using the greedy algorithm [100], then analysed using Bayesian inference in MrBayes with 1,000,000 MCMC simulations, a burnin of 250,000 and sample frequency of 1000 . In BI, ML and MP analyses, Merrillia (Aurantieae) (accession 23-IJW), Murraya kwangsiensis (accession 98-CGX) and/or M. microphylla (accession 99-CH) were used as outgroup(s).

\section{Incongruence length difference (ILD) test}

Because analyses of multiple data sets do not result in mutual agreement of phylogenetic relationships, ILD tests were performed using the partition homogeneity test as implemented in PAUP*. The ILD tests were conducted between those different chloroplastal data sets that were representative of the different nucleotide substitution models determined by MrModeltest. ILD tests were also performed between the combined chloroplastal data set and the ITS dataset. A second ILD test was conducted on these data sets with accessions 24-IP, 91$\mathrm{T}, 92-\mathrm{T}$ and 93-T excluded. These are accessions of $M$. omphalocarpa and are the ones that caused significant incongruence in the topology of trees derived from chloroplastal and ITS data.

\section{Testing the monophyly of Murraya and dating of divergence}

The BEAST v. 1.6.1 package [101] was used to produce chronograms for molecular dating and to test the monophyly of Murraya rigorously by including a broad range of outgroup taxa. Two sets of sequence data were examined (Additional file 1: Table S2). Firstly, ITS sequences for selected accessions of Murraya and 26 accessions of the Rutaceae and Simaroubaceae were analysed using the age calibration points in Appelhans et al. [51] for Clausena, 'Euodia 2' and Ailanthus to define the priors for, respectively, the Bergera/Clausena, Euodia/Toddalia/Zanthoxylum and the Simarouba/Ailanthus crown nodes. A lognormal prior $($ mean $=1$; s.e. $=0.3$; offset $=$ 82) was assigned to the Rutaceae using the age range obtained by Appelhans et al. [51] and the GTR + G model of sequence evolution, identified as appropriate by MrModetest, was used. Prior to analysis, RDP2 [102] was used to examine the sequence data for recombination; no recombination was found. Secondly, data from the five chloroplastal regions were analysed for Murraya accessions and 10 accessions of other genera of Rutaceae. The calibration data for Clausena were again used, the root height of the tree was defined with the lognormal prior for the Rutaceae as above, and there were separate partitions for each DNA region each assuming the HYK model of evolution, identified as appropriate by MrModeltest. For both analyses, an uncorrelated, relaxed clock model [103] assuming a lognormal distribution of rates and a randomly generated starting tree were used, and the tree priors were set to the birthdeath process $[104,105]$. TRACER v. 1.7.1 [106] was used to check for chain convergence, appropriate burnin values and effective sample sizes. 


\section{Supplementary information}

Supplementary information accompanies this paper at https://doi.org/10. 1186/s12862-019-1555-4

Additional file $\mathbf{1}$ Table S1. List of accessions of Murraya and Merrillia used for molecular phylogenetic analyses and the locations from which they were sourced. Table S2. GenBank accession numbers for the regions used to determine the monophyly and dating of divergence of the Murraya accessions. Figure S1. Phylogenetic analysis of the combined sequences of six chloroplastal regions from accessions of Murraya and Merrillia. Figure S2. 50\% majority-rule bootstrap consensus tree based on the indels of six chloroplastal regions from accessions of Murraya and Merrillia derived from maximum parsimony analysis. Figure S3. Phylogenetic analysis by of the ITS regions of accessions of Murraya. Figure S4. Bayesian inference tree based on the 6 chloroplastal regions combined with the ITS region of accessions of Murraya and Merrillia following partitioning and model selection using PartitionFinder 2 (Lanfear et al. 2016) using the greedy algorthim (Lanfear et al. 2012).

\section{Acknowledgements}

The following people provided Murraya specimens or DNA extracts of Murraya accessions:

Dr Trịnh Xuân Hoạt, Plant Protection Research Institute (PPRI), Phư ng Đức Th ng, Quận B c T Liêm, Hà Nội, Việt Nam;

Dr. Siti Subandiyah, Faculty of Agriculture, Gadjah Mada University, Indonesia; Dr. Shahid Nadeem Chohan, Department of Biosciences, COMSATS Institute of Information Technology, Islamabad, Pakistan;

Dr. Cen Yijing and Dr. Deng Xiaoling and their students at South China Agricultural University;

Prof Zhang Dianxiang, South China Botanical Garden;

Dr. Hung Shih-Cheng, Plant Protection Department, Chiayi Agricultural Experiment Branch, Agricultural Research Institute, Council of Agriculture, Yuan, Taiwan;

Dr. Chandrika Ramadugu, University of California, Riverside, United States of America;

Dr. Susan Halbert, Division of Plant Industry Entomology, Florida Department of Agriculture and Consumer Services, United States of America;

Dr. Silvio Lopes, Fundo de Defesa da Citricultura, São Paulo, Brazil;

Mr. Fanie Venter, Botanical \& Environmental Consultant, Queensland,

Australia;

Mr. Graham Schultz, Biosecurity and Product Integrity, Department of Regional Development, Primary Industry, Fisheries and Resources, Darwin, Australia.

\section{Authors' contributions}

$\mathrm{GACB}, \mathrm{AMH}$, and $\mathrm{PH}$ conceived and designed the study and revised the manuscript. CHN conducted the experiments, analyzed the data and wrote and revised the manuscript. PH and $\mathrm{AMH}$ analyzed the data. IPA contributed to the conduct of the experiments and revised the manuscript. DJM and $\mathrm{PHW}$ revised the manuscript. All authors approved the final manuscript.

\section{Funding}

This work was partially funded by a John Allwright Fellowship from the Australian Centre for International Agricultural Research to CHN, Western Sydney University, and the Plant Protection Research Institute, Hanoi, Việt Nam.

Availability of data and materials

All sequences generated during this study have been uploaded to Genbank.

\section{Ethics approval and consent to participate}

Not applicable.

\section{Consent for publication}

Not applicable.

\section{Competing interests}

All authors declare that they have no conflict of interest.

\section{Author details}

'Plant Protection Research Institute, Phư' ng Đức Th ng, Quận B C T Liêm, Hà Nội, Việt Nam. ${ }^{2}$ School of Science, Western Sydney University, Locked Bag 1797, Penrith, NSW 2751, Australia. ${ }^{3}$ Bogor Botanic Garden, Paledang, Tengah, Kota Bogor, Bogor, Jawa Barat 16122, Indonesia. ${ }^{4}$ National Herbarium of New South Wales, Royal Botanic Garden, Mrs Macquaries Road, Sydney, NSW 2000, Australia. ${ }^{5}$ Wadham College, University of Oxford, Oxford, UK. ${ }^{6}$ Department of Biological Sciences, Macquarie University, Sydney, NSW 2109, Australia.

Received: 9 April 2019 Accepted: 9 December 2019

Published online: 30 December 2019

\section{References}

1. Mabberley DJ. The typification of Murraya, M. exotica, and M. paniculata (Rutaceae): its significance for the world citrus industry. Taxon. 2016;65(2): 366-71

2. Mabberley DJ. (2433) proposal to conserve the name Chalcas paniculata (Murraya paniculata) (Rutaceae) with a conserved type. Taxon. 2016;65(2): 394-5.

3. Swingle WT, Reece CR. The botany of Citrus and its wild relatives. In: Reuther W, Webber HJ, Batchelor LD, editors. The Citrus Industry. Berkeley: Division of Agricultural Sciences, University of California; 1967. p. 190-430.

4. Rumphius GE. Herbarium Amboinense, vol. 5. Amsterdam: M. Uytwerf after Amsterdam; 1747

5. Jack W. Descriptions of Malayan plants. Malayan Miscellanies. 1820;1:31-3.

6. Burkill $\mathrm{H}$. A dictionary of economic products of the Malay peninsula. London: Crown Agent for the Colonies; 1935.

7. Aziz S, Sukari M, Rahmani M, Kitajima M, Aimi N, Ahpandi N. Coumarins from Murraya paniculata (Rutaceae). Malaysian J Analytical Sci. 2010;14(1):1-5.

8. Kong YC, Cheng KF, Ng KH, But PPH. Qianli, Yu SX, Chang HT, Cambie RC, Kinoshita T, Kan WS et al: a chemotaxonomic division of Murraya based on the distribution of the alkaloids yuehchukene and girinimbine. Biochem Syst Ecol. 1986;14(5):491-7.

9. Bitters W, Brusca J, Cole D. The search for new citrus rootstocks. California Citrograph. 1964;49:443-8.

10. Bové JM. Huanglongbing: a destructive, newly-emerging, century-old disease of citrus. J Plant Pathol. 2006;88(1):7-37.

11. Halbert SE, Manjunath KL. Asian citrus psyllids (Sternorrhyncha : Psyllidae) and greening disease of citrus: a literature review and assessment of risk in Florida. Fla Entomol. 2004:87(3):330-53.

12. $\mathrm{Li} \mathrm{T}, \mathrm{Ke} \mathrm{C}$. Detection detection of the bearing rate of Liberobacter asiaticum in the citrus psylla and its host plant Murraya paniculata by nested PCR. Acta Phytophylacica Sinica. 2002;29:31-5.

13. Lopes SA. Huanglongbing in Brazil. In: International Workshop for the Prevention of Citrus Greening Disease in Severely Infected Areas, Ishigaki, Japan, 6-7 December 2006. Tokyo: Multilateral Research Network for Food and Agricultural Safety. Japanese Ministry of Agriculture, Forestry and Fisheries; 2006. p. 11-9.

14. Zhou LJ, Gabriel DW, Duan YP, Halbert SE, Dixon WN. First report of dodder transmission of Huanglongbing from naturally infected Murraya paniculata to Citrus. Plant Dis. 2007:91(2):227.

15. Walter AJ, Duan Y, Hall DG. Titers of 'Ca. Liberibacter asiaticus' in Murraya paniculata and Murraya-reared Diaphorina citri are much lower than in Citrus and Citrus-reared psyllids. HortScience. 2012;47(10):1449-52.

16. Miyakawa T. Experimentally-induced symptoms and host range of citrus likubin (greening disease). Ann Phytopathol Soc Jpn. 1980;46:224-30.

17. Garnier M, Bové JM. Citrus greening disease and the greening bacterium. In: Moreno P, da Graça JV, Timmer LW, editors. Proceedings of the Twelfth Conference of the International Organization of Citrus Virologists, New Delhi, India, 23-27 November 1992. Riverside: International Organization of Citrus Virologists, University of California, Riverside; 1993. p. 212-9.

18. Dai K, Ikeshiri T, Matsuura T, Kimura S, Hamagami A, Fujiwara $Y$, Kobashigawa Y, Miyakuni S. Investigation of host range of Candidatus Liberibacter asiaticum - is Murraya paniculata a host plant of Candidatus L. asiaticum? Res Bull Plant Protection Serv(Japan). 2005;41:53-7.

19. Cifuentes-Arenas JC, Beattie GAC, Pena L, Lopes SA. Murraya paniculata and Swinglea glutinosa as short-term transient hosts of 'Candidatus Liberibacter asiaticus' and implications for spread of huanglongbing. Phytopathology. 2019;109(12):2067-73. https://doi.org/10.1094/PHYTO-06-19-0216-R. 
20. de Araújo EF, de Queiroz LP, Machado MA. What is Citrus? Taxonomic implications from a study of cp-DNA evolution in the tribe Citreae (Rutaceae subfamily Aurantioideae). Org Divers Evol. 2003;3:55-62.

21. Morton CM, Grant M, Blackmore S. Phylogenetic relationships of the Aurantioideae inferred from chloroplast DNA sequence data. Am J Bot. 2003:90(10):1463-9.

22. Pfeil BE, Crisp MD. The age and biogeography of Citrus and the orange subfamily (Rutaceae: Aurantioideae) in Australasia and New Caledonia. Am J Bot. 2008;95(12):1621-31.

23. Morton CM. Phylogenetic relationships of the Aurantioideae (Rutaceae) based on the nuclear ribosomal DNA ITS region and three noncoding chloroplast DNA regions, atpB-rbcL spacer, rps 16, and trnL-trnF. Org Diver Evol. 2009;9(1):52-68

24. Bayer RJ, Mabberley DJ, Morton C, Miller CH, Sharma IK, Pfeil BE, Rich S, Hitchcock R, Sykes S. A molecular phylogeny of the orange subfamily (Rutaceae: Aurantioideae) using nine cpdna sequences. Am J Bot. 2009; 96(3):668-85.

25. Penjor T, Anai T, Nagano Y, Matsumoto R, Yamamoto M. Phylogenetic relationships of Citrus and its relatives based on $r b c L$ gene sequences. Tree Gen Genom. 2010;6(6):931-9.

26. Samuel R, Ehrendorfer F, Chase MW, Greger H. Phylogenetic analyses of Aurantioideae (Rutaceae) based on non-coding plastid DNA sequences and phytochemical features. Plant Biol. 2001;3(1):77-87.

27. Linnaeus C. Mantissa Plantarum. Generum editionis VI. Et Specierum editionis II. Stockholm, Sweden: Salvius; 1767.

28. Linnaeus C. Mantissa Plantarum. Altera. Generum editionis VI. Et Specierum editionis II. Regni animalis appendix. Stockholm: Salvius; 1771.

29. Jarvis C. Order out of Chaos: Linnaean plant names and their types. London: Linnean Society of London and Natural History Museum; 2007.

30. Hooker JD. The Flora of British India, vol. 1. London: L Reeve; 1875.

31. Briquet J. Règles internationales de la nomenclature botaniques adoptées par le Congrès International de Botanique de Vienne 1905. Jena: Gustav Fischer; 1906.

32. Zhang DX, Hartley TG, Mabberley DJ. Rutaceae. In: Wu ZY, Raven PH, Hong DY, editors. Flora of China, vol. 11 (Oxalidaceae through Aceraceae). St. Louis, USA, Beijing, China: Science Press and Missouri Botanical Garden Press; 2008.

33. Li Q, Zhu LF, But PPH, Kong YC, Chang HT, Waterman PG. Monoterpene and sesquiterpene rich oils from the leaves of Murraya species chemotaxonomic significance. Biochem Syst Ecol. 1988;16(5):491-4.

34. Ito Y, Tanaka N, Barford AS, Bogner J, Li J, Yano O, Gale SW. Molecular phylogenetic species deliminitation in the aquatic genus Ottelia (Hydrocharitaceae) reveals cryptic diversity within a widespread species. J Plant Res. 2019;132:335-44.

35. But PPH, Kong YC, Ng KH, Chang HT, Li Q, Yu SX, Waterman PG. A chemotaxonomic study of Murraya (Rutaceae) in China. Acta Phytotaxonomica Sinica. 1986;24:186-92.

36. Mou FJ. Systematics of Clauseninae (Rutaceae). Beijing: Graduate School of the Chinese Academy of Sciences; 2009

37. Nguyen $\mathrm{CH}$. Circumscription of Murraya and Merrillia (Sapindales: Rutaceae: Aurantioideae) and susceptibility of species and forms to huanglongbing. Richmond, NSW: Western Sydney University; 2011.

38. Tanaka T. Chalcas, a Linnean genus which includes many new types of Asiatic plants. J Soc Trop Agric. 1929;1:23-44.

39. Wendel JF, Doyle J. Phylogenetic incongruence: window into genome history and molecular evolution. In: Soltis DE, Soltis PS, Doyle JJ, editors. Molecular systematics of plants. Boston, USA: Kluwer Academic Publishers; 1998.

40. Seelanan T, Schnabel A, Wendel JF. Congruence and consensus in the cotton tribe (Malvaceae). Syst Bot. 1997;22(2):259-90.

41. Barber JC, Finch CC, Francisco-Ortega J, Santos-Guerra A, Jansen RK. Hybridization in Macaronesian Sideritis (Lamiaceae): evidence from incongruence of multiple independent nuclear and chloroplast sequence datasets. Taxon. 2007:56(1):74-88.

42. Barrett RA, Bayly MJ, Duretto MF, Forster PI, Ladiges PY, Cantrill DJ. Phylogenetic analysis of Zieria (Rutaceae) in Australia and New Caledonia based on nuclear ribosomal DNA shows species polyphyly, divergent paralogues and incongruence with chloroplast DNA. Aust Syst Bot. 2018; 31(1):16-47.

43. Galtier N, Daubin V. Dealing with incongruence in phylogenomic analyses. Philos Trans R Soc B Biol Sci. 2008;363(1512):4023-9.

44. Joly S, Starr JR, Lewis WH, Bruneau A. Polyploid and hybrid evolution in roses east of the Rocky Mountains. Am J Bot. 2006;93(3):412-25.
45. Arnold ML, Hodges SA. Are natural hybrids fit or unfit relative to their parents. Trends Ecol Evol. 1995;10(2):67-71.

46. Arnold ML. Natural hybridization and evolution. New York, USA: Oxford University Press; 1997.

47. Raven P. Hybridization and the nature of species in higher plants. Can Bot Assoc Bull. 1980;13:3-10.

48. Mallet J. Hybridization as an invasion of the genome. Trends Ecol Evol. 2005 20(5):229-37.

49. Rieseberg LH, Whitton J, Linder CR. Molecular marker incongruence in plant hybrid zones and phylogenetic trees. Acta Botanica Neerlandica. 1996;45(3): 243-62.

50. Tippery NP, Les DH. Evidence for the hybrid origin of Nymphoides montana Aston (Menyanthaceae). Telopea. 2011;13(1-2):285-94.

51. Appelhans MS, Kessler PJA, Smets E, Razafimandimbison SG, Janssens SB. Age and historical biogeography of the pantropically distributed Spathelioideae (Rutaceae, Sapindales). J Biogeogr. 2012;39(7):1235-50.

52. Pigram CJ. Terranes and the accretion history of the Papua New Guinea orogen. AGSO J Aust Geol Geophys. 1987;10:193-211.

53. Hall R. Cenozoic reconstructions of SE Asia and the SW Pacific: changing patterns of land and sea. In: Metcalfe I, Smith JMB, Morwood M, Davidson ID, editors. Faunal and floral migrations and evolution in SE Asia-Australasia. Lisse, Netherlands: Swets and Zeitlinger; 2001. p. 35-56.

54. Hall R. Cenozoic geological and plate tectonic evolution of SE Asia and the SW Pacific: computer-based reconstructions, model and animations. J Asian Earth Sci. 2002;20(4):353-431.

55. Sanmartin I, Ronquist F. Southern hemisphere biogeography inferred by event-based models: plant versus animal patterns. Syst Biol. 2004;53(2):216-43.

56. Lohman DJ, de Bruyn M, Page T, von Rintelen K, Hal R, Ng PKL, Shih HT, Carvalho GR, von Rintelen T. Biogeography of the Indo-Australian archipelago. Ann Rev Ecol Evol Syst. 2011;42:205-26.

57. Stone BC, Jones DT. New and noteworthy Rutaceae: Aurantioideae from northern Borneo. Studies in Malesian Rutaceae, V. Proc Acad Natl Sci Phila. 1988;140(2):267-74.

58. Lim TK. Merrillia caloxylon, Edible and Non-Medicinal Plants, vol. 4, Fruits. Dordrecht: Springer; 2012. p. 890-2.

59. Carlquist S. Plant dispersal and the origin of Pacific island floras. In: Keast A, Miller SE, editors. The origin and evolution of Pacific island biotas, New Guinea to eastern Polynesia: patterns and processes. Amsterdam: SPB Academic Publishing; 1996. p. 153-64.

60. Muellner AN, Pannell CM, Coleman A, Chase MW. The origin and evolution of Indomalesian, Australasian and Pacific island biotas: insights from Aglaieae (Meliaceae, Sapindales). J Biogeogr. 2008;35(10):1769-89.

61. Crayn DM, Costion C, Harrington MG. The Sahul-Sunda floristic exchange: dated molecular phylogenies document Cenozoic intercontinental dispersal dynamics. J Biogeogr. 2015;42:11-24.

62. Sniderman JMK, Jordan GJ. Extent and timing of floristic exchange between Australian and Asian rain forests. J Biogeogr. 2011;38(8):1445-55.

63. Burman NL. Flora Indica: cui accedit series zoophytorum indecorum, nec non Prodromus Florae Capensis. Amsterdam: Haek; 1768.

64. Florijn PJ. Geschiedenis van de errste hortus medicus in Indië. Tijdschrift voor de Geschiedenis der Geneeskunde, Natuurwetenschappen, Wiskunde en Techniek, vol. 8; 1985. p. 209-21.

65. Florijn PJ. Biographical notes about four plant collectors in Asia mentioned by NL Burman in his Flora Indica (1768). Taxon. 1987;36:34-8.

66. Mabberley DJ. Mabberley's plant-book: a portable dictionary of plants, their classification and uses. 4th ed. Cambridge: Cambridge University Press; 2017

67. Forster G. Florulae insularum australium prodromus. Dieterich: Göttingen, Germany; 1786.

68. Hockings D. Mock orange Murraya paniculata var. ovatifoliolata 'Min-A-Min'. Plant Var J. 1998;11:27.

69. Lindley J. Edwards's botanical register: consisting of coloured figures of exotic plants, cultivated in British gardens; with their history and mode of treatment, vol. 5. James Ridgeway: London; 1819.

70. Burkill IH. William Jack's letters to Nathaniel Wallich, 1819-1821. J Straits Branch R Asian Soc. 1916:73:147-268.

71. Beattie G, Holford P, Mabberley D, Haigh A, Bayer R, Broadbent P. Aspects and insights of Australia-Asia collaborative research on huanglongbing. In: Proceedings of the international workshop for the prevention of citrus greening disease in severely infected areas. Tokyo: Ministry of Agriculture, Forestry and Fisheries Tokyo; 2006. p. 7-9. 
72. Merrill ED. William Jack's genera and species of Malaysian plants. J Arnold Arboretum. 1952;33:199-251.

73. Hunter W. Plants of Prince of Wales Island. J Straits Branch R Asiatic Soc. 1909;53:49-127.

74. Jones DT. Rutaceae. In: Soepadmo E, Wong K, editors. Tree Flora of Sabah and Sarawak, vol. 1. Malaysia: Forest Research Institute Malaysia, Sabah Forestry Department and Sarawak Forestry Department; 1995. p. 1351-419.

75. Kurz S. Contributions towards a knowledge of the Burmese flora. J Asiatic Soc Bengal. 1874;44:128-90.

76. Kurz S. Forest Flora of British Burma, vol. 1. Calcutta, India: Office of the Superintendent of Government Printing; 1877.

77. Gamble JS. A manual of Indian timbers; an account of the growth, distribution, and uses of the trees and shrubs of India and Ceylon with descriptions of their wood-structure. London: Sampson Low; 1902.

78. Brandis D. Indian trees: an account of trees, shrubs, woody climbers, bamboos and palms indigenous or commonly cultivated in the British Indian empire. London: Constable; 1906.

79. Huang CC. Flora Reipublicae Popularis Sinicae. Beijing: Science Press; 1997. p. 43(2).

80. Om N. The roles of psyllids, host plants and environment in the aetiology of huanglongbing in Bhutan. Richmond: Western Sydney University; 2017.

81. Hollis D. A new citrus-feeding psyllid from the Comoro Islands, with a review of the Diaphorina amoena species group (Homoptera). Syst Entomol. 1987;12(1):47-61.

82. Lopes SA, Frare GF, Camargo LEA, Wulff NA, Teixeira DC, Bassanezi RB, Beattie GAC, Ayres AJ. Liberibacters associated with orange jasmine in Brazil: incidence in urban areas and relatedness to citrus liberibacters. Plant Pathol. 2010;59(6):1044-53.

83. Doyle JJ, Doyle LL. Isolation of plant DNA from fresh tissue. Focus. 1990;12:13-5.

84. Warude D, Chavan P, Joshi K, Patwardhan B. DNA isolation from fresh, dry plant samples with highly acidic tissue extracts. Plant Mol Biol Report. 2012; 21(4):467.

85. Murray MG, Thompson WF. Rapid isolation of high molecular weight plant DNA. Nucleic Acids Res. 1980;8(19):4321-5.

86. Taberlet P, Gielly L, Pautou G, Bouvet J. Universal primers for amplification of three non-coding regions of chloroplast DNA. Plant Mol Biol. 1991;17(5): 1105-9.

87. Shaw J, Lickey EB, Beck JT, Farmer SB, Liu W, Miller J, Siripun KC, Winder CT, Schilling EE, Small RL. The tortoise and the hare II: relative utility of 21 noncoding chloroplast DNA sequences for phylogenetic analysis. Am J Bot. 2005;92(1):142-66.

88. Demesure B, Sodzi N, Petit RJ. A set of universal primers for amplification of polymorphic non-coding regions of mitochondrial and chloroplast DNA in plants. Mol Ecol. 1995;4(1):129-31.

89. Oxelman B, Liden M, Berglund D. Chloroplast rps16 intron phylogeny of the tribe Sileneae (Caryophyllaceae). Plant Syst Evol. 1997;206(1-4):393-410.

90. Johnson LA, Soltis DE. matk DNA-sequences and phylogenetic reconstruction in Saxifragaceae s. str. Syst Bot. 1994;19(1):143-56.

91. White TJ, Bruns T, Lee S, Taylor J. Amplification and direct sequencing of fungal ribosomal RNA genes for phylogenetics. In: Innis MA, Gelfand DH, Sninsky JJ, White TJ, editors. PCR protocols: a guide to methods and applications. New York: Academic Press; 1990. p. 315-22.

92. Thompson JD, Higgins DG, Gibson TJ. Clustal-W - improving the sensitivity of progressive multiple sequence alignment through sequence weighting, position-specific gap penalties and weight matrix choice. Nucleic Acids Res. 1994;22(22):4673-80.

93. Hall TA. BioEdit: a user-friendly biological sequence alignment editor and analysis program for windows 95/98/NT. Nucleic Acids Symp Ser. 1999:41:95-8.

94. Swofford DL. PAUP* — phylogenetic analysis using parsimony * and other methods beta version 40b10. Sunderland: Sinauer Associates; 2002.

95. Simmons MP, Ochoterena H. Gaps as characters in sequence-based phylogenetic analyses. Syst Biol. 2000;49(2):369-81.

96. Kumar S, Strecher G, Tamura K. MEGA7: molecular evolutionary genetics analysis version 7.0 for bigger datasets. Mol Biol Evol. 2019;33(7):1870-4

97. Ronquist F, Huelsenbeck JP. MrBayes, v. 3: bayesian phylogenetic inference under mixed models. Bioinformatics. 2003;19:539-42.

98. Nylander JAA. MrModeltest V2. Program distributed by the author. Uppsala: Evolutionary Biology Centre, Uppsala University; 2004.
99. Lanfear R, Calcott B, Ho S, Guindon S. PartitionFinder: combined selection of partitioning schemes and substitution models for phylogenetic analyses. Mol Biol Evol. 2012;29(6):1695-701.

100. Rambaut A, Drummond AJ, Xie D, Baele G, Suchard MA. Posterior summarisation in Bayesian phylogenetics using Tracer 1.7. Syst Biol. 2018; 67(5):901-4.

101. Drummond AJ, Rambaut A. BEAST: Bayesian evolutionary analysis by sampling trees. BMC Evol Biol. 2007;7:214.

102. Martin DP, Williamson C, Posada D. RDP2: recombination detection and analysis from sequence alignments. Bioinformatics. 2005;21(2):260-2.

103. Drummond AJ, Ho SY, Phillips MJ, Rambaut A. Relaxed phylogenetics and dating with confidence. PLOS Biol. 2006;4:e88.

104. Yule GU. A mathematical theory of evolution, based on the conclusions of Dr. J. C. Willis, F.R.S. Philos Trans R Soc B Biol Sci. 1925;213(402-410):21-87.

105. Gernhard T. The conditioned reconstructed process. J Theor Biol. 2008; 253(4):769-78.

106. Rambaut A, Drummong AJ, Xie W, Baele G, Suchard MA: Tracer: MCMC trace analysis tool v. 1.7.1 2003-2018.

\section{Publisher's Note}

Springer Nature remains neutral with regard to jurisdictional claims in published maps and institutional affiliations.
Ready to submit your research? Choose BMC and benefit from:

- fast, convenient online submission

- thorough peer review by experienced researchers in your field

- rapid publication on acceptance

- support for research data, including large and complex data types

- gold Open Access which fosters wider collaboration and increased citations

- maximum visibility for your research: over $100 \mathrm{M}$ website views per year

At BMC, research is always in progress.

Learn more biomedcentral.com/submissions 